\title{
Manifestasi Klinis Refluks Laringofaring: Studi pada Anak Usia 0-24 Bulan dengan Laringomalasia
}

\author{
Melati Sudiro, ${ }^{1}$ R. Ayu Hardianti Saputri, ${ }^{1}$ Teti Madiadipoera, ${ }^{1}$ M. Thaufiq S. Boesoirie, ${ }^{1}$ \\ Budi Setiabudiawan ${ }^{2}$ \\ ${ }^{1}$ Departemen Ilmu Kesehatan THT-KL Fakultas Kedokteran Universitas Padjadjaran/Rumah Sakit Dr. Hasan \\ Sadikin Bandung, ${ }^{2}$ Departemen Ilmu Kesehatan Anak Fakultas Kedokteran Universitas Padjadjaran \\ Rumah Sakit Dr. Hasan Sadikin Bandung
}

\begin{abstract}
Abstrak
Laringomalasia merupakan kelainan kongenital anomali laring yang banyak ditemukan pada bayi baru lahir dan penyebab tersering stridor serta obstruksi saluran napas. Pemeriksaan laringoskopi serat lentur memperlihatkan terlipat atau terhisapnya struktur supraglotik ke dalam laring selama inspirasi. Obstruksi saluran napas pada laringomalasia akan menyebabkan tekanan negatif intratorakal, menyebabkan asam lambung naik ke jaringan laringofaring dan diduga menimbulkan refluks laringofaring (RLF). Telah dilakukan penelitian dengan pendekatan potong lintang yang bertujuan mengidentifikasi dan menilai hubungan antara laringomalasia dan gambaran refluks laringofaring pada usia 0-24 bulan yang datang ke poliklinik THT-KL RSHS Bandung periode Januari 2012-Maret 2015 berdasar atas data rekam medis dan hasil pemeriksaan laringoskopi serat lentur. Seratus tujuh pasien laringomalasia dengan keluhan stridor mengikuti penelitian ini, 69 laki-laki $(64,5 \%)$ dan 38 perempuan $(35,5 \%)$ dengan usia rata-rata 4,19 bulan. Laringomalasia tipe 1 merupakan tipe terbanyak (57,9\%). Gambaran RLF yang berhubungan dengan tingkat berat laringomalasia adalah edema plika ventrikularis dengan OR 3,71 (IK 95\%=1,07-12,91; p=0,039) dan edema aritenoid dengan OR 4,74 (IK 95\%=1,19-18,89; p=0,027). Edema ventrikular dan aritenoid merupakan gambaran RLF yang berhubungan dengan tingkat berat laringomalasia pada pada anak usia 0-24 bulan. [MKB. 2017;49(2):115-21]
\end{abstract}

Kata kunci: Edema aritenoid, edema plika ventrikularis, laringomalasia, refluks laringofaring

\section{Laryngopharyngeal Reflux Manifestation: a Case Study of Laryngomalacia in Children Aged 0-24 Months}

\begin{abstract}
Laryngomalacia is the most common laryngeal anomaly of the newborn and the main cause of stridor and airway obstruction in infants. From a flexible laryngoscopy examination, this anomaly is observed as curled or collapsed supraglottic structures into larynx during inspiration. Airway obstruction in laryngomalacia creates a negative intra-thoracal pressure that causes acid reflux to laryngopharynx tissue and is suspected to cause laryngopharyngeal reflux (LPR). A cross-sectional study was conducted with the objectives of identifying and assessing the relationship between laryngomalacia and LPR in patients aged 0-24 months who visited the Ear, Nose, Throat, Head, and Neck Clinic of Dr. Hasan Sadikin General Hospital Bandung in the period of January 2012-March 2015, which was based on medical records and results of flexible laryngoscopy. A hundred and seven patients diagnosed with laryngomalacia who experienced stridor symptoms in this study consisted of 69 males (64.5\%) and 38 females (35.5\%) with mean age of 4.19 months. Type-1 laryngomalacia represents the most cases (57.9\%). Indication of LPR sign correlated with type of laryngomalacia is ventricular edema OR 3.71 (CI 95\%=1.07-12.91; p=0.039) and arytenoid edema OR 4,74 (CI 95\%=1.19-18.89; p=0.027). Ventricular and arytenoid edemas are signs of LPR that correlate with laryngomalacia level in patients aged 0-24 months. [MKB. 2017;49(2):115-21]
\end{abstract}

Key words: Arytenoid edema, laringomalacia, laringopharyngeal reflux, ventricular edema

Korespondensi: Melati Sudiro, dr., M.Kes., SpTHT-KL(K), Departemen Ilmu Kesehatan THT-KL Fakultas Kedokteran Universitas Padjadjaran/Rumah Sakit Dr. Hasan Sadikin Bandung, Jalan Pasteur No. 38 Bandung, E-mail: lati_tht@yahoo.com 


\section{Pendahuluan}

Laringomalasia merupakan kelainan kongenital anomali laring yang banyak ditemukan pada neonatus dan penyebab paling sering stridor, obstruksi saluran napas pada bayi. Keluhan stridor dan biasanya dikenali orangtua sebagai bunyi/suara napas dengan nada tinggi yang terjadi akibat aliran udara napas menembus daerah obstruksi, saat bayi tidur dalam posisi terlentang dan akan bertambah buruk saat makan. Pada bayi dapat terjadi berhenti makan sementara untuk bernapas. ${ }^{1-3}$

Karakteristiknya itu ditandai dengan terlipat atau terhisapnya struktur supraglotik ke dalam laring selama inspirasi. Bentuk laring pada bayi tidak semua mempunyai anatomi yang sama, namun semua bayi memperlihatkan struktur supraglotis yang potensial untuk terlipat saat inspirasi. ${ }^{1,2}$

Angka kejadian laringomalasia di dunia belum pasti, namun diduga mengenai $60-70 \%$ bayi dengan stridor kongenital di mana laki-laki dua kali lebih banyak daripada perempuan. ${ }^{4}$ Tiga teori dasar yang diduga sebagai dasar terjadi laringamalasia, yaitu teori imaturitas kartilago menyatakan kartilago merupakan struktur laring yang terbentuk secara imatur dan lunak, namun teori ini disanggah melalui temuan histologis pada bayi dengan gejala laringomalasia yang menunjukan kartilago yang normal. Teori kedua bentuk anatomi, menyatakan terdapat jaringan abnormal di daerah laring yang lunak dan menimbulkan stridor, tetapi teori ini disangkal dengan ditemukannya bayi gejala laringomalasia, namun tidak terjadi obstruksi jalan napas. Teori terakhir, imaturitas neuromuskular yang paling banyak diterima dengan dugaan terjadi hipotonus laring yang menyebabkan keterlambatan dalam kontrol gerakan neuromuskular laring.,56

Terdapat berbagai faktor komorbid yang akan memengaruhi perjalanan penyakit gejala laringomalasia ini. Penyakit neurologis, sindrom kongenital, penyakit jantung, dan juga refluks laringofaringeal merupakan kondisi yang dapat memperburuk gejala laringomalasia. Namun, refluks gastroesofageal atau ektraesofageal yang paling sering dilaporkan. 2,4

Sebanyak $65 \%$ bayi laringomalasia berat mengalami refluks, utamanya gastroesofageal refluks. Hartl dan Chaddha $^{1}$ pada suatu penelitian metaanalisis menemukan $65 \%$ bayi laringomalasia berat mengalami refluks dan 10 kali lebih sering mengalaminya daripada pasien laringomalasia ringan. Pada bayi laringomalasia yang mengalami stridor akan terjadi peningkatan tekanan udara di intratorakal sehingga dapat menyebabkan gangguan pada spinkter esofagus dan terjadilah refluks. ${ }^{1,7}$

Peristiwa terjadi aliran balik isi lambung secara retrograd menuju laringofaring dikenal sebagai refluks laringofaring (RLF). Aliran retrograd tersebut akan membuat iritasi pada mukosa laring, edema, dan menambah buruk aliran udara pernapasan. Refluks yang terjadi terus menerus dapat berkontribusi terhadap penurunan sensitivitas laring yang akan dapat menambah risiko tersedak dan aspirasi. Edema mukosa dan inflamasi pada struktur laring dapat memperberat laringomalasia ${ }^{1,8,9}$

Pada bayi, pada saat menelan memerlukan fungsi koordinasi yang baik antara mengisap, menelan, dan bernapas untuk menghindari aspirasi sehingga diperlukan sensasi neurologik laring yang utuh untuk proses tersebut. Secara patofisiologis mukosa daerah supraglotis harus mampu mengenali dan merasakan masuknya bolus makanan/minuman yang akan membuat pita suara menutup sekaligus merangsang pembukaan daerah hipofaring dan juga spinkter upper oesophageal. Berbeda dengan orang dewasa mekanisme menelan menjadi penting pada bayi sehingga terjadi edema di area laring akibat refluks iritasi kronis. ${ }^{6}$

Diagnosis laringomalasia tersebut ditegakkan berdasar atas anamnesis yang dikonfirmasi melalui pemeriksaan laringoskopi serat lentur. Refluks laringofaring pada bayi maupun anak sulit dikenali bila hanya melalui anamnesis. Pemeriksaan baku emas untuk mengetahui RLF sama dengan pada refluks gastroesofageal, yaitu menggunakan $\mathrm{pH}$-metri double probe monitoring 24 jam, namun beberapa peneliti menyatakan pemeriksaan ini tidak tepat dilakukan pada pasien dengan gejala klinis pada laring oleh karena sampai sekarang belumlah didapatkan kesepakatan nilai batas $\mathrm{pH}$ normal laring.

Seorang ahli THT-KL dianjurkan melihat langsung kondisi laring (direct laryngoscopy) dengan menggunakan laringoskopi fiberoptik. ${ }^{4,7}$ Gambaran RLF pada bayi dapat terlihat sebagai edema postglotik, eritema postglotik, edema aritenoid, eritema aritenoid, hipertrofi tonsil lingualis, edema pada pita suara sejati, edema plika ventrikularis, hipertrofi komisura posterior, atau terdapatnya mukus di endolaring.

May dkk. ${ }^{11}$ berpendapat terdapat hubungan refluks gastroesofageal atau RLF dengan gambaran berupa edema dan eritema aritenoid, hipertrofi tonsil lingualis, edema dan eritema glotis posterior, edema trakea, edema plika ventrikularis, dan vokalis serta stenosis glotis. 
Namun sampai saat ini belum ada konsesus kriteria pasti RLF pada bayi dan anak. Berbeda pada orang dewasa diagnosis RLF itu dapat ditegakkan berdasar atas reflux finding score yang diperkenalkan oleh Belafsky, Postma, and Koufman pada tahun 2001. ${ }^{10,11}$

Gambaran RLF pada bayi dan anak sampai saat ini belum didapatkan ketetapan diagnosis objektif. Oleh karena itu, para peneliti ingin mengetahui gambaran RLF sebagai komorbid pada bayi/anak menderita laringomalasia dan besar risiko gambaran RLF yang didapatkan terhadap tingkat berat laringomalasia.

\section{Metode}

Penelitian analitik komparatif kategorik tidak berpasangan memakai desain potong lintang dilakukan untuk menilai gambaran RLF pada bayi usia 0-24 bulan, stridor dan diduga laringomalasia serta untuk mencari hubungan antara gambaran RLF dan tipe laringomalasia.

Subjek dalam penelitian ini diambil dari data rekam medis pasien bayi dengan gejala stridordan suspect laringomalasia yang datang ke poliklinik THT-KL RSHS/FKUP pada periode Januari 2012-Maret 2015 dan rekam medis video laringoskopi serat lentur menggunakan Olympus Evis Exera II MAJ-1430.

Penilaian skor tipe laringomalasia dilakukan berdasar atas kriteria Kay dan Goldsmith ${ }^{12}$ melalui pemeriksaan videolaringoskopi serat lentur yang terdiri atas: tipe 1. plika ariepiglotika tampak rapat/pendek dengan epiglotis berbentuk omega; tipe 2: tampak jaringan lunak yang redundant pada daerah supraglotis; tipe 3:. epiglotis prolaps saat inspirasi. Gambaran RLF berdasar atas temuan edema postglotik, eritema postglotik, edema aritenoid, eritema aritenoid, hipertrofi tonsil lingualis, edema pada pita suara sejati, edema plika ventrikularis, hipertrofi komisura posterior, atau terdapat mukus di endolaring. Uji chi-square dipilih bila data normal dan bila tidak dilakukan uji MannWhitney dengan tingkat kebermaknaan $\mathrm{p}<0,05$. Penelitian disetujui oleh Komisi Etik Penelitian Kesehatan Fakultas Kedokteran Universitas Padjadjaran Bandung, Nomor 436/UN6.C1.3.2/ KEPK/PN/2016.

\section{Hasil}

Seratus tujuh bayi ikut dalam penelitian. Terdiri atas 69 orang laki-laki $(64,5 \%)$ dan 38 orang perempuan $(35,5 \%)$ dengan usia rentang $0-24$ bulan dengan usia rata-rata 4,19 bulan. Kelompok usia 3-6 bulan merupakan pasien dengan usia laringomalasia terbanyak, diperoleh sebesar 35 orang $(32,7 \%)$. Karakteristik laringomalasia yang menunjukkan bentuk epiglotis memanjang dan berbentuk omega paling banyak ditemukan, yaitu 62 pasien $(57,9 \%)$.

Penderita laringomalasia disertai dengan bronkopneumonia merupakan subjek yang paling banyak kedua ditemukan, yaitu pada 44 pasien (41\%). Hubungan bivariat antara RLF dan tipe laringomalasia disajikan pada Tabel 2. Gejala RLF yang sudah diikutsertakan kedalam analisis multivariat adalah gejala yang pada analisis bivariat mempunyai nilai $\mathrm{p}<0,05$, yaitu mukus endolaring, hipertrofi komisura posterior, edema plika ventrikularis, dan edema aritenoid. Tidak terdapat perbedaan bermakna karakteristik usia, jenis kelamin, penyakit peserta bronkopneumonia, kelainan jantung, bronkopneumonia disertai cerebral palsy dan hipotiroid kongenital dengan gambaran RLF ( $>00,05)$

Pada penelitian ini diperoleh 5 gambaran RLF, yaitu mukus pada endolaring ditemukan pada 44 pasien $(41 \%)$, hipertrofi komisura posterior pada 29 pasien $(27 \%)$, edema plika ventrikularis pada 10 pasien $(9 \%)$, hipertrofi tonsila lingualis pada 3 pasien (3\%) dan edema aritenoid pada 8 pasien $(8 \%)$, dari data tersebut terlihat dari seluruh subjek penelitian yang memperlihatkan minimal 1 sampai 2 gambaran klinis RLF.

Analisis multivariat regresi ordinal antara

Tabel 1 Karakteristik Tipe Laringomalasia dan Komorbid

\begin{tabular}{lcc}
\hline Karakteristik Laringomalsia & $\mathbf{n}$ & $\mathbf{6}$ \\
\hline Tipe Laringomalsia & 62 & 57,9 \\
$\quad$ Tipe 1 & 34 & 31,8 \\
$\quad$ Tipe 2 & 11 & 10,3 \\
$\quad$ Tipe 3 & & \\
Komorbid & & \\
$\quad$ Tanpa komorbid & 44 & 47,7 \\
$\quad$ Bronkopneumonia & 44 & 41,1 \\
$\quad$ Bronkopneumonia + \\
cerebral palsy & 7 & 6,5 \\
$\quad$ Kelainan jantung & & 3,8 \\
$\quad$ Hipotiroid kongenital & 4 & 0,9 \\
\hline
\end{tabular}


Tabel 2 Hubungan antara Refluks laringofaring dan Gambaran Refluks Laringomalasia

\begin{tabular}{|c|c|c|c|c|c|c|c|c|c|c|}
\hline & \multicolumn{8}{|c|}{ Tipe laringomalasia } & \multirow{2}{*}{\multicolumn{2}{|c|}{ IK 95\% }} \\
\hline & \multicolumn{2}{|c|}{ Tipe 3} & \multicolumn{2}{|c|}{ Tipe 2} & \multicolumn{2}{|c|}{ Tipe 1} & \multirow[t]{2}{*}{ Nilai p } & \multirow[t]{2}{*}{ OR } & & \\
\hline & $\mathbf{n}$ & $\%$ & $\mathbf{n}$ & $\%$ & $\mathbf{n}$ & $\%$ & & & Min. & Maks. \\
\hline \multicolumn{11}{|l|}{ Mukus } \\
\hline Positif & 6 & 14 & 19 & 43 & 19 & 43 & 0,014 & 2,63 & 1,22 & 5,69 \\
\hline Negatif & 5 & 8 & 15 & 24 & 43 & 68 & & & & \\
\hline \multicolumn{11}{|c|}{$\begin{array}{l}\text { Hipertropi komisura } \\
\text { posterior }\end{array}$} \\
\hline Positif & 4 & 14 & 13 & 45 & 12 & 41 & 0,048 & 2,30 & 1,01 & 5,27 \\
\hline Negatif & 7 & 9 & 21 & 27 & 50 & 64 & & & & \\
\hline \multicolumn{11}{|c|}{ Ventrikular edema } \\
\hline Positif & 2 & 20 & 5 & 50 & 3 & 30 & 0,069 & 3,14 & 0,92 & 10,74 \\
\hline Negatif & 9 & 9 & 29 & 30 & 59 & 61 & & & & \\
\hline \multicolumn{11}{|c|}{ Hipertropi T lingualis } \\
\hline Positif & 1 & 33 & 0 & 0 & 2 & 67 & 0,932 & 1,10 & 0,12 & 10,33 \\
\hline Negatif & 10 & 10 & 34 & 33 & 60 & 58 & & & & \\
\hline \multicolumn{11}{|c|}{ Aritenoid edema } \\
\hline Positif & 2 & 25 & 4 & 50 & 2 & 25 & 0,047 & 3,98 & 1,02 & 15,60 \\
\hline Negatif & 9 & 9 & 30 & 30 & 60 & 61 & & & & \\
\hline Total & 11 & 10 & 34 & 32 & 62 & 58 & & & & \\
\hline
\end{tabular}

nilai p,oods rasio dan IK 95\% diperoleh melalui prosedur regresi ordinal

RLF dan tipe Laringomalasia disajikan pada Tabel 3. Berdasarkan atas analisis tersebut, gejala RLF yang secara statistik berhubungan dengan beratnya laringomalasia adalah edema ventrikular dan edema aritenoid. Subjek dengan edema ventrikular positif mempunyai nilai odds

Tabel 3 Analisis Multivariat Regresi Ordinal Hubungan Gambaran RLF dengan beratnya Laringomalasia

\begin{tabular}{llcccccc}
\hline & & Koefisien & df & Nilai p & OR & \multicolumn{2}{c}{ IK95\% } \\
\cline { 6 - 8 } & & & & & Min. & Maks. \\
\hline \multirow{2}{*}{ Step 1 } & Mukus (+) & 0,689 & 1 & 0,187 & 1,99 & 0,72 & 5,53 \\
& Hipertropi komisura & $-0,163$ & 1 & 0,784 & 0,85 & 0,26 & 2,74 \\
& Posterior (+) & & & & & & \\
& Edema Ventrikular (+) & 1,126 & 1 & 0,124 & 3,08 & 0,74 & 12,93 \\
& Edema Aritenoid (+) & 1,211 & 1 & 0,112 & 3,36 & 0,75 & 14,98 \\
\multirow{2}{*}{ Step 2 } & Mukus (+) & 0,616 & 1 & 0,160 & 1,85 & 0,78 & 4,37 \\
& Edema Ventrikular (+) & 1,044 & 1 & 0,117 & 2,84 & 0,77 & 10,48 \\
& Edema Aritenoid (+) & 1,164 & 1 & 0,125 & 3,20 & 0,73 & 14,13 \\
& Edema Ventrikular (+) & 1,311 & 1 & 0,039 & 3,71 & 1,07 & 12,91 \\
& Edema Aritenoid (+) & 1,556 & 1 & 0,027 & 4,74 & 1,19 & 18,89 \\
\hline
\end{tabular}

Keterangan: Pembandingnya adalah hasil pemeriksaan negatif 
3,71 kali untuk mengalami laringomalasia yang lebih berat bila dibanding dengan subjek edema ventrikular negatif. Selanjutnya, subjek dengan aritenoid edema positif mempunyai odds 4,74 kali untuk mengalami laringomalasia yang lebih berat dibanding dengan subjek aritenoid edema negatif.

\section{Pembahasan}

Pada penelitian ini didapatkan jumlah subjek laki-laki lebih banyak apabila dibanding dengan perempuan dengan perbandingan 1,8:1. Sedikit berbeda dengan penelitian Nasution dkk. ${ }^{13}$ yang mendapatkan hasil 1,6:1. Bentuk laring gender laki-laki utamanya pada usia prepubertas diduga lebih pendek daripada perempuan dan dapat menjadi salah satu faktor risiko. Edmonson, ${ }^{14}$ Fattah dkk. ${ }^{15}$ telah memperlihatkan hasil yang mirip bahwa jumlah laki-laki yang menderita laringomalasia lebih tinggi dibanding dengan perempuan. Kemungkinan hal ini disebabkan oleh perbedaan perkembangan anatomi saluran napas antara laki-laki dan perempuan.

Terdapat $58 \%$ penderita laringomalasia tipe 1 pada penelitian ini, sesuai dengan penelitian Kay dan Golds Smith ${ }^{12}$ yang mendapatkan $50 \%$ kasus adalah laringomalasia tipe 1 , sedikit berbeda dengan Vijayasekaran dkk. ${ }^{16}$ mendapatkan 48\% laringomalasia tipe1. Pada laringomalasia melalui teori imaturitas neurologis sel saraf di perifer, nukleus di batang otak dan jarasjarasnya bertanggung jawab terhadap proses menelan dan juga keutuhan mekanisme jalan napas. Pada bayi, bentuk epiglotis memang memperlihatkan ukuran yang lebih panjang dibanding dengan anak yang lebih besar usianya, selain itu dapat juga berbentuk tubular atau omega. Kelainan anatomi pada laringomalasia tipe 2 menurut Manning dkk., memperlihatkan bentuk plika ariepiglotika pada bayi dengan laringomalasia berat lebih pendek daripada bayi tanpa petanda laringomalasia berat. Hal ini mungkin disebabkan oleh bentuk anatomi aritenoid yang tebal dan lebar disertai mukosa yang flasida pada pasien dengan stridor berat atau pengaruh ratio panjang plika ariepiglotika sehingga besar aritenoid memengaruhi beratnya laringomalasia. ${ }^{4-6}$

Lebih dari 50\% subjek penelitian ini mempunyai penyakit penyerta atau komorbid berupa kelainan jantung, kelainan neurologis, maupun infeksi. Proses infeksi yang terjadi pada 2 bulan kehidupan akan memengaruhi perkembangan sistem pernapasan termasuk sistem kardiovaskular, demikian pula sebaliknya kelainan neurologis yang terbawa sejak lahir akan memengaruhi perkembangan sistem organ lain. ${ }^{2,4}$

Pada penelitian ini $44 \%$ subjek penelitian memperlihatkan gambaran RLF, hal ini sesuai dengan pendapat Ayari dkk., ${ }^{3}$ Landry dan Thomson, ${ }^{2}$ Hartl dan Chadha, ${ }^{1}$ dan Nasution dkk. $^{13}$ yang menyatakan refluks laringofaring yang pada bayi diduga merupakan kelanjutan dari refluks gastroesofageal merupakan penyakit penyerta atau komorbid yang tersering dan berhubungan erat dengan laringomalasia. Hal ini dapat dikarenakan pada saat terjadi obstruksi saluran napas atas maka akan terjadi peningkatan tekanan negatif di dalam rongga paru yang akan mengganggu fungsi pertahanan spinkter esofagus. Gangguan ini akan mengakibatkan refluks atau aliran balik isi lambung atau reflusat ke arah laring yang akan menyebabkan edema atau eritema di daerah laring. Akibatnya, struktur supraglotik dapat melipat ke dalam laring, asam lambung yang terus berkontak dengan mukosa dapat menurunkan sensasi laring saat proses menelan dan berakibat sering tersedak atau tercekik akibat aspirasi. Belum dapat ditentukan apakah refluks yang lebih dulu menyebabkan laringomalasia atau malah kondisi sebaliknya. Pada penelitian hewan coba tikus terlihat bahwa refluksat yang mengandung pepsin maupun isi cairan usus secara signifikan akan mengubah gambaran histologis mukosa laring. ${ }^{17}$ Berbeda dengan lambung, laring tidak mempunyai kemampuan secara intrinsik untuk melawan asam lambung, akibatnya dapat terjadi kerusakan epitel yang dimulai pada saat $\mathrm{pH}$ di daerah esofagus mencapai angka 5.,8

Analisis multivariat regresi ordinal pada penelitian ini memperlihatkan bahwa secara statistik gambaran edema aritenoid sebagai akibat refluks pada penderita laringomalasia mempunyai Odds ratio 4,74 kali untuk mengalami laringomalasia dengan tipe yang lebih berat, yaitu tipe 3 maupun tipe 2 dibanding dengan subjek tidak terdapat edema aritenoid. Edema plika ventrikularis dengan Odds ratio 3,71 kali mempunyai hubungan untuk mengalami laringomalasia yang lebih berat. Hal ini sesuai dengan pendapat Ozmen dkk. bahwa dalam penelitian retrospektif terhadap 49 pasien (usia 1-16 tahun) dengan keluhan stidor, mereka menemukan 12 dari 30 pasien didiagnosis RLF dengan temuan laringoskopi serat lentur terbanyak adalah eritema dan edema aritenoid. May dkk. ${ }^{11}$, melalui telaah pada 8 artikel penelitian mendapatkan gambaran laringoskopi 
serat lentur yang signifikan dengan RLF berupa edema aritenoid $(\mathrm{RR}=2,46)$, hipertrofi tonsila lingualis $(\mathrm{RR}=2,24)$, edema post glotik $(R R=3,19)$, edema trakea (RR 1,86), dan stenosis subglotis ( $R R=2,5)$.

Namun secara klinis temuan mukus pada endolaring dapat juga menjadi gambaran RLF pada bayi usia $0-24$ bulan dengan Odds rRatio 1,85 . Hal ini sesuai dengan Leone dkk yang memperkenalkan suatu kriteria penilaian RLF pada bayi, yaitu reflux finding score for infants (RFS-I) yang dapat digunakan hanya untuk menilai keadan klinis. Mereka menyatakan yang berhubungan dengan RLF pada bayi hanya edema, serta eritema laring dan tampaknya mukus endolaring di pita suara. ${ }^{7}$ Pada penderita laringomalasia yang disertai bronkopneumonia, terdapat sekret kental kemungkinan turut memperberat RLF melalui penurunan sensasi laring utamanya di daerah pita suara dapat menyebabkan edema atau eritema laring.

Simpulan, hubungan antara laringomalasia dan refluks laringofaring sering ditemukan pada bayi. Berbagai penelitian memperlihatkan dan menduga satu sama lain dapat menjadi penyebab, namun kendala timbul oleh karena belum terdapat konsesus diagnostik bagi RLF pada bayi dan anak. Penelitian ini menunjukan bahwa gambaran edema aritenoid, edema plika ventrikularis, dan terdapat mukus di endolaring pada pasien laringomalasia usia 0-24 bulan dapat digunakan sebagai petanda RLF. Temuan edema aritenoid mempunyai risiko 4,74 kali untuk mengalami laringomalasia dengan tipe yang lebih berat.

\section{Daftar Pustaka}

1. Hartl TT, Chadha NK. A systematic review of laryngomalacia and acid reflux. Otolaryngol Head Neck Surg. 2012;147(4):619-26.

2. Landry AM, Thompson DM. Laryngomalacia: disease presentation, spectrum, and management. Int J Pediatr. 2012;2012:1-6.

3. Ayari S, Aubertin G, Girschig H, Van Den Abbeele T, Mondain M. Pathophysiology and diagnostic approach to laryngomalacia in infants. Eur Ann Otorhinolaryngol Head Neck Dis. 2012;129(5):257-63.

4. Thorne MC, Garetz SL. Laryngomalacia: review and summary of current clinical practice in 2015. Paediatr Respir Rev. 2016;17:3-8.
5. van der Heijden M, Dikkers FG, Halmos GB. The groningen laryngomalacia classification system--based on systematic review and dynamic airway changes. Pediatr Pulmonol. 2015;50(12):1368-73.

6. Ayari S, Aubertin G, Girschig H, Van Den Abbeele T, Denoyelle F, Couloignier V, dkk. Management of laryngomalacia. Eur Ann Otorhinolaryngol Head Neck Dis. 2013;130(1):15-21.

7. Galluzzi F, Schindler A, Gaini RM, Garavello W. The assessment of children with suspected laryngopharyngeal reflux: an Ootorhinolaringological perspective. Int J Pediatr Otorhinolaryngol. 2015;79(10): 1613-9.

8. Patel D, Vaezi MF. Normal esophageal physiology and laryngopharyngeal reflux. Otolaryngol Clin North Am. 2013; 46(6):1023-41.

9. Venkatesan NN, Pine HS, Underbrink M. Laryngopharyngeal reflux diseasein children. Pediatr Clin North Am. 2013;60(4):865-78.

10. Campagnolo AM, Priston J, Thoen RH, Medeiros T, Assuncao AR. Laryngopharyngeal reflux: diagnosis, treatment, and latest research. Int Arch Otorhinolaryngol. 2014;18(2):184-91.

11. May JG, Shah P, Lemonnier L, Bhatti G, Koscica J, Coticchia JM. Systematic review of endoscopic airway findings in children with gastroesophageal reflux disease. Ann Otol Rhinol Laryngol. 2011;120(2):116-22.

12. Kay DJ, Goldsmith AJ. Laryngomalacia: a classification system and surgical treatment strategy. Ear Nose Throat J. 2006;85(5):32836.

13. Nasution DP, Tamin S, Hutauruk S, Bardosono S. Prevalensi refluks laringofaring pada bayi laringomalasia primer. Oto Rhino Laryngologica Indonesia. 2012;42(2):112-8.

14. Edmondson NE, Bent JP, Chan C. Laryngomalacia: the role of gender and ethnicity. Int J Pediatr Otorhinolaryngol. 2011;75(12):1562-4.

15. Fattah HA, Gaafar AH, Mandour ZM. Laryngomalacia: diagnosis and management. j.ejenta. 2011;12(3):149-53.

16. Vijayasekaran D, Gowrishankar NC, Kalpana S, Vivekanandan VE, Balakrishnan MS, Suresh S. Lower airway anomalies in infants with laryngomalacia. Indian J Pediatr. 2010;77(4):403-6.

17. Habesoglu M, Habesoglu TE, Gunes P, 
Kinis V, Toros SZ, Eriman M, dkk. How does reflux affect laryngeal tissue quality? An experimental and histopathologic animal study. Otolaryngol Head Neck Surg. 2010;143(6):760-4. 